\title{
Androgen receptors are acquired by healthy postmenopausal endometrial epithelium and their subsequent loss in endometrial cancer is associated with poor survival
}

\author{
AM Kamal ${ }^{1,2}$, J N Bulmer ${ }^{3}$, S B DeCruze ${ }^{4}$, H F Stringfellow ${ }^{5}$, P Martin-Hirsch ${ }^{5}$ and D K Hapangama*,1,4 \\ ${ }^{1}$ Department of Women's and Children's Health, Institute of Translational Medicine, University of Liverpool, Liverpool L8 7SS, UK; \\ ${ }^{2}$ The National Center for Early Detection of Cancer, Oncology Teaching Hospital, Baghdad Medical City, Baghdad, Iraq; ${ }^{3}$ Institute \\ of Cellular Medicine, Newcastle University, Newcastle upon Tyne NE2 4HH, UK; ${ }^{4}$ Liverpool Women's Hospital NHS Foundation \\ Trust, Liverpool L8 7SS, UK and ${ }^{5}$ Lancashire Teaching Hospital NHS Trust, Lancaster University, Preston PR2 9HT UK
}

Background: Endometrial cancer $(E C)$ is a hormone-driven disease, and androgen receptor (AR) expression in high-grade EC (HGEC) and metastatic EC has not yet been described.

Methods: The expression pattern and prognostic value of $A R$ in relation to oestrogen (ER $\alpha$ and $E R \beta)$ and progesterone (PR) receptors, and the proliferation marker Ki67 in all EC subtypes $(n=85)$ were compared with that of healthy and hyperplastic endometrium, using immunohistochemisty and qPCR.

Results: Compared with proliferative endometrium, postmenopausal endometrial epithelium showed significantly higher expression of $A R(P<0.001)$ and $E R \alpha(P=0.035)$, which persisted in hyperplastic epithelium and in low-grade EC (LGEC). High-grade EC showed a significant loss of AR $(P<0.0001)$, PR $(P<0.0001)$ and $\operatorname{ER} \beta(P<0.035)$ compared with LGEC, whilst maintaining weak to moderate ER $\alpha$. Unlike $P R$, AR expression in metastatic lesions was significantly $(P=0.039)$ higher than that in primary tumours. Androgen receptor expression correlated with favourable clinicopathological features and a lower proliferation index. Loss of AR, with/without the loss of PR was associated with a significantly lower disease-free survival $(P<0.0001, P<0.0001$, respectively)

Conclusions: Postmenopausal endometrial epithelium acquires AR whilst preserving other steroid hormone receptors. Loss of AR, $P R$ with retention of ER $\alpha$ and $E R \beta$ may promote the unrestrained growth of HGEC. Androgen receptor may therefore be a clinically relevant prognostic indicator and a potential therapeutic target in EC.

Endometrial cancer (EC) is the commonest gynaecological malignancy in the developed world, with an increasing incidence related to obesity (Cancer Research UK, 2013; Lindemann et al, 2010). Traditional classifications of EC are based either on clinical and endocrine features (e.g., types I and II; Bokhman, 1983) or on histopathological characteristics (e.g., endometrioid, serous and clear-cell carcinomas, and carcinosaroma; Murali et al, 2014). More recently, a molecular classifier that can be combined with clinicopathological features to predict outcome has also been proposed (Kandoth et al, 2013; Talhouk et al, 2015) In contrast with previous reports, recent data suggest that type I and II ECs may share common aetiological factors, including their response to/stimulation by oestrogen and other ovarian steroid hormones (Setiawan et al, 2013).

The endometrium is the main target organ for ovarian hormones, and steroid hormones are implicated in carcinogenesis

*Correspondence: Dr DK Hapangama; E-mail: dharani@liv.ac.uk

Revised 19 October 2015; accepted 22 December 2015; published online 1 March 2016

(c) 2016 Cancer Research UK. All rights reserved 0007-0920/16

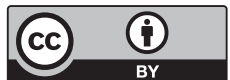

B) $C$ 
in endometrium and other classical hormone-responsive tissues such as breast and prostate. Endometrial cancer is generally a disease of the postmenopausal (PM) period that is defined by cessation of the cyclical production of ovarian hormones. As these hormones exert their effect via their cognate receptors, in common with other hormone-responsive cancers such as breast cancer (Tagnon, 1977; Thike et al, 2001), the hormone receptor status of ECs would be expected to have a role in predicting clinical outcome and guiding therapeutic choice (Zhang et al, 2015). Unlike breast cancer (Breast Cancer Consensus C et al, 1994), steroid receptor status is not routinely reported for EC, yet increasingly clinical oncologists in the UK seek this information in high-grade EC to make therapeutic decisions beyond standard surgery (Singh et al, 2007).

Defining the contribution of all steroid receptors (including AR, which has not been described in detail in EC previously), to the initiation, progression and prognosis of EC will improve the understanding of the hormonal changes that precede and potentially drive EC tumorigenesis.

In this study, the spatial and temporal expression pattern of AR in normal and hyperplastic PM endometrium was compared with that of healthy proliferative phase (PP) endometrium. The expression profile of $\mathrm{AR}$ in $\mathrm{EC}$ was investigated and compared with endometrium from healthy PM women. Expression of AR, $\mathrm{ER} \alpha, \mathrm{ER} \beta, \mathrm{PR}$ and the proliferation marker Ki67 was correlated in normal (premenopausal PP and PM), hyperplastic and malignant endometrium to gain a better insight in to the interplay between oestrogens, progesterone and androgens in healthy and neoplastic endometrium. Finally, the prognostic value of AR and other sex hormone receptors in EC was evaluated.

\section{MATERIALS AND METHODS}

Patient population. Patient groups are detailed in Table 1. A total of $85 \mathrm{EC}, 16$ metastatic lesions (3 lymph node, 7 soft tissue, 3 parametrium and 3 omentum), 12 hyperplastic (4 without cytological atypia, EHNA; 8 with cytological atypia, EHA) and 28 full-thickness normal endometrial biopsies were collected from patients undergoing hysterectomy in Liverpool Women's Hospital and Lancashire Teaching Hospitals Trusts from 2009 to 2014. The study was approved by Liverpool and Cambridge Adult Research Ethics Committee (LREC 09/H1005/55, 11/H1005/4 and CREC 10/ $\mathrm{H} 0308 / 75)$. The histological type and grade of EC specimens were assigned by experienced gynaecological pathologists according to the International Federation of Gynecology and Obstetrics (FIGO; Zaino et al, 1995). Endometrial cancer was categorised as lowgrade (LGEC, including grade 1 and grade 2 endometrioid EC) or high-grade tumours (HGEC, including grade 3 endometrioid, serous and clear-cell carcinomas, and carcinosarcoma) (Voss et al, 2012) for subsequent analysis of immunohistochemistry (IHC) data (Table 1). Proliferative phase specimens were assigned according to last menstrual date and histological criteria (Noyes et al, 1950; Dallenbach-Hellweg et al, 2010). All samples were split in to two; one was fixed ( $\geqslant 24 \mathrm{~h}$ in $4 \%(\mathrm{v} / \mathrm{v})$ buffered formalin) and paraffin-embedded for immunohistochemical staining, and the other part was immediately placed into RNAlater (Sigma, Dorset, UK) for RNA extraction for PCR.

Patient clinicopathological and demographic details were retrieved by review of hospital notes and clinical databases. None of the patients received hormonal treatments, chemotherapy or pelvic radiation before surgery.

Immunohistochemistry. After antigen retrieval at $\mathrm{pH} 6$ as previously described (Hapangama et al, 2012) $3 \mu \mathrm{m}$ formalin-fixed paraffin-embedded tissue sections were immunostained with antihuman steroid receptor antibodies and Ki67; antibody sources, concentrations and incubation conditions are detailed in Supplementary Table 1. Detection was with the ImmPRESS polymer-based system and visualisation was with ImmPACT DAB (Vector Laboratories, Peterborough, UK) used in accordance with the manufacturer's instructions. Sections were lightly counterstained in Gill 2 Haematoxylin (Thermo Scientific, Runcorn, UK), dehydrated, cleared and mounted in synthetic resin. Matching isotype $(0.5 \mu \mathrm{g} \mathrm{ml})$ replaced the primary antibody as a negative control, with internal positive controls performed in each staining run.

Analysis of IHC staining. Immunostaining for the four steroid receptors was assessed semi-quantitatively using a four-tiered Liverpool endometrial steroid quick score (LESQS). The final score out of 12 was calculated by multiplying the proportion of positive cells $(1-10 \%=1,11-20 \%=2,21-40 \%=3$ and $>40 \%=4)$ by the staining intensity categories $(0=$ no staining, $1=$ weak, $2=$ moderate and $3=$ strong). The detailed description, optimisation and validation of this scoring system are presented in Supplementary Methods. The Ki67 proliferative index (PI) was evaluated as the percentage of immunopositive cells, of any

Table 1. Demographic features of study groups

\begin{tabular}{|c|c|c|c|c|}
\hline Study groups & Number of cases & $\%$ & $\mathrm{Age}^{\mathrm{a}}$ (years) & $\mathrm{BMI}^{\mathrm{b}}\left(\mathrm{kg} \mathrm{m}^{-2}\right)$ \\
\hline Proliferative phase & 14 & & $39(30-47)$ & $26.7(17.5-45.5)$ \\
\hline Postmenopausal & 14 & & $68.5(57-79)$ & $26.3(22.7-35.8)$ \\
\hline Endometrial hyperplasia & 12 & & $50(37-67)$ & $29.7(34.3)$ \\
\hline $\begin{array}{l}\text { Without cytological atypia } \\
\text { With cytological atypia }\end{array}$ & $\begin{array}{l}4 \\
8\end{array}$ & & $\begin{array}{l}55(50-62) \\
52(37-67)\end{array}$ & $\begin{array}{r}25.75(23.6-53.2) \\
34(27.9-57.8)\end{array}$ \\
\hline Endometrial cancer & 85 & & $67(41-89)$ & $30(20.2-54.4)$ \\
\hline $\begin{array}{l}\text { LGEC } \\
\text { Grade1 endometrioid } \\
\text { Grade2 endometrioid } \\
\text { HGEC } \\
\text { Grade3 endometrioid } \\
\text { Serous } \\
\text { Clear cell } \\
\text { Carcinosarcoma }\end{array}$ & $\begin{array}{r}37 \\
19 \\
18 \\
48 \\
15 \\
7 \\
12 \\
14\end{array}$ & $\begin{array}{r}43.5 \\
22.4 \\
21.2 \\
56.5 \\
17.6 \\
8.2 \\
14.1 \\
16.5\end{array}$ & $\begin{array}{r}63.5(41-84) \\
63(46-84) \\
63.5(41-83) \\
70(51-89) \\
69(51-83) \\
68(64-82) \\
69(52-82) \\
54.5(59-89)\end{array}$ & $\begin{aligned} 30.8 & (21.6-46.1) \\
35.7 & (21.6-46.1) \\
29 & (22.3-54.4) \\
29.6 & (20.2-54.4) \\
26.7 & (22.1-42.7) \\
29.5 & (24.8-34.9) \\
29.9 & (25.4-31.5) \\
28.6 & (20.2-37.2)\end{aligned}$ \\
\hline Metastatic lesions & 16 & & $68(41-89)$ & b \\
\hline \multicolumn{5}{|c|}{$\begin{array}{l}\text { Abbreviations: } \mathrm{BMI}=\text { body mass index; HGEC = high-grade endometrial carcinoma; LGEC = low-grade endometrial carcinoma. } \\
{ }^{a} \text { Data expressed as median (range). } \\
\text { b }_{\text {BMI data were available for only } 60 \text { cases. }}\end{array}$} \\
\hline
\end{tabular}


intensity. The entire section was evaluated at $\times 400$ magnification as previously described (Al Kushi et al, 2002).

Epithelial and stromal cell staining was scored separately in PM, and malignant endometrium and stratum basalis of healthy $\mathrm{PP}$ endometrium by two independent observers (AMK and DKH). Discrepencies between the two observers were resolved by reevaluating the samples together and agreeing on a final score.

For the purpose of description, scores 1-4 were considered as low, 5-8 as moderate and 9-12 as high levels of expression. For survival analysis and correlation with clinicopathological analysis, data were subclassified as immunopositive when $>10 \%$ of the neoplastic cells expressed the target protein at any intensity (LESQS $\geqslant 2$ ) and immunonegative if $<2$ (Pertschuk et al, 1996).

RT-qPCR. Total RNA from tissue samples was extracted using TRIzol Plus RNA Purification System (Life Technologies, Paisley, UK), and quantified by NanoDrop ND-1000 (Thermo Fisher Scientific, Loughborough, UK). Total RNA was reverse transcribed using AMV First Strand cDNA synthesis kit (New England Bio Labs, Hertfordshire, UK) after DNase treatment (DNase I (\#M0303), New England Bio Labs, Hertfordshire, UK), using the manufacturer's protocol. cDNA was amplified by qPCR using JumpStart SYBR Green supermix (Sigma, Dorset, UK ) and the Light Cycler 96 Roche Real-Time System (Roche Diagnostics Ltd. BurgessHill, UK). Primers are listed in Supplementary Table 2. Relative transcript expression was calculated by the $\Delta \Delta \mathrm{CT}$ method, normalised to the reference gene YWHAZ (Sadek et al, 2011) using Biogazelle qbase + software (Biogazelle NV, Zwijnaarde, Belgium)

Statistical analysis. Statistical differences between groups were calculated by non-parametric tests (Kruskal-Wallis and/or MannWhitney $U$-test or Wilcoxon signed-rank test) using Statistical Package for the Social Sciences (SPSS) version 21 (IBM Corp, Armonk, NY, USA). Descriptive values were presented as median and range. The correlations between immunoexpression scores were examined with Spearman test, and association between immunoscores and the multiple clinicopathological parameters with Pearson $\chi^{2}$. Disease-free survival (DFS) was calculated from the date of surgery to the date of recurrence, death or the date on which the patient was last seen. For survival analysis each parameter was categorised, and survival curves were obtained using the KaplanMeier method. The Cox proportional hazards regression model was used to identify the independent prognostic factors. Only variables with $P<0.05$ in the univariate analysis were included in the multivariate model. $P<0.05$ was considered significant.

\section{RESULTS}

Demographic data. Patient demographics are detailed in Table 1. Women with HGEC were significantly older than those with LGEC $(P<0.0001)$. Patients with EHA were significantly younger than those with LGEC $(P=0.016)$. Healthy PM controls had the lowest BMI compared with women who had EHA $(P=0.007)$ and LGEC $(P=0.022)$. There was no significant difference in BMI between LGEC and HGEC.

IHC analysis of AR and other steroid receptor expression. All four steroid receptors were expressed by the endometrium (Figure 1). The main focus of interest, AR, was expressed by both the epithelium and stroma. At a subcellular level, both cytoplasmic and nuclear AR staining was observed; only nuclear immunostaining suggesting transcriptionally active AR with functional relevance was scored and semi-quantified.

Healthy PM endometrial epithelial cells aquire AR and preserve ERs and PR. The dominant steroid receptor in both epithelium and stroma of the healthy endometrium was PR. In PP endometrium, AR expression was largely limited to stromal cells in both the stratum basalis and functionalis with absent epithelial AR staining (Supplementary Figure 1a). In contrast, the most striking feature of non-proliferating $\mathrm{PM}$ endometrium was the emergence of nuclear AR immunopositivity $(P<0.001)$ in the epithelial cells (Figure 2A). Compared with epithelial cells in PP stratum basalis, PM epithelial cells also expressed significantly higher levels of $\operatorname{ER} \alpha(P=0.035)$ (Figure 2C and Supplementary Table 3); however, there were no differences in $\operatorname{ER} \beta$ and PR expression scores or in the $\mathrm{ER} \alpha / \mathrm{ER} \beta$ ratio. The stromal expression scores for both PM and PP stratum basalis were similar for all the steroid receptors examined (Supplementary Table 3).

AR expression and $\operatorname{ER} \alpha / \operatorname{ER} \beta$ ratio is increased in atypical endometrial hyperplasia. PR expression was the strongest of the steroid receptors in both epithelial and stromal compartments of EH (Supplementary Table 3). Interestingly, compared with PP epithelium, nuclear AR expression was significantly higher in the epithelial cells in EHA $(P=0.025)$, but no significant change was observed when compared with PM epithelium (Figures 2A and C). Endometrial stroma in EHA showed significant loss of AR expression compared with PP stroma $(P<0.0001)$. The general trend of ER $\alpha$ epithelial expression in EHA was higher than that of PP $(P=0.076)$ and PM $(P=0.547)$. In contrast, the trend of $\operatorname{ER} \beta$ expression in EHA was lower than that of PP $(P=0.128)$ and significantly lower compared with PM endometrium $(P=0.014$, Figure $2 \mathrm{C}$ ). Thus, $\mathrm{ER} \alpha / \mathrm{ER} \beta$ in EHA was generally higher than that of normal endometrium; this was significant compared with PP $(P=0.041)$.

In common with $\mathrm{AR}$, both $\operatorname{ER} \alpha(P=0.043)$ and $\operatorname{ER} \beta(P=0.045)$ expression scores were significantly decreased, whereas $\mathrm{PR}$ was increased $(P=0.02)$ in the stroma of EHA compared with PM endometrium. Epithelial PR expression levels were preserved at a level that was comparable to that of healthy PP and PM samples. The PI, assessed by Ki67 immunopositivity, of epithelial cells in EHNA and EHA was similar to that of PP epithelium but, as expected, was significantly higher than PM epithelium (EHNA $P=0.016$, EHA $P=0.017$, Supplementary Figure $1 b$ ).

AR, PR and ER $\beta$ are downregulated in HGEC. We chose healthy $\mathrm{PM}$ tissue as the healthy comparator for steroid receptor expression scores of EC samples. $\mathrm{ER} \beta$ was the predominant steroid receptor expressed in both LGEC and HGEC (Figures 1 and 2C). AR $(P=0.10$, Figures 1 and $2 \mathrm{~A}$ and $\mathrm{C})$ and $\operatorname{ER} \alpha(P=0.05$, Figure $2 \mathrm{C})$ staining scores showed a trend to being increased in LGEC, with simultaneous reduction in $\mathrm{PR}(P=0.08$, Figure 2C). This was associated with a significant reduction in stromal expression of $\mathrm{AR}$ $(P<0.0001$, Figure 2B), ER $\alpha(P<0.0001)$ and $\mathrm{PR}(P<0.0001)$ when compared with healthy PM controls. There was no significant change in ER $\beta$ scores (stromal and epithelial) of LGECs compared with healthy controls, although the $\mathrm{ER} \alpha / \mathrm{ER} \beta$ ratio was higher in LGEC compared with PP $(P<0.0001)$; and PM $(P=0.02)$.

The epithelial cells of HGEC and the surrounding stroma showed a general reduction in the expression of all four steroid receptors compared with healthy PM tissue (Supplementary Table 3). Compared with LGEC, in HGEC epithelial AR $(P<0.0001), \operatorname{PR}(<0.0001)$ and $\operatorname{ER} \beta \quad(P=0.035)$ scores were significantly lower (Figures 1 and $2 \mathrm{~A}$ and $\mathrm{C}$ ). Within the subtypes of HGEC, the most pronounced loss of AR was observed in the clear-cell carcinoma group $(P=0.001)$; albeit $\mathrm{ER} \alpha$ expression scores in the same group remained moderate to strong (Figure 2D). Weak to moderate cytoplasmic AR was observed in 33\% (11 out of 33) HGEC in the absence of nuclear staining (Figure 1, serous). The expression scores for both PR $(P<0.0001)$ and ER $\beta \quad(P=0.003)$ in HGEC epithelial cells and surrounding stroma $P R(P<0.0001)$ and $\operatorname{ER} \beta(P=0.02$; Figure $2 \mathrm{C})$ were significantly lower than healthy $\mathrm{PM}$ counterparts. Interestingly, in non-endometrioid HGEC, 26 out of 33 (78.8\%) showed loss of PR whilst all were $\operatorname{ER} \beta+$, and 30 out of $33(90.9 \%)$ were also ER $\alpha+$. Progesterone 


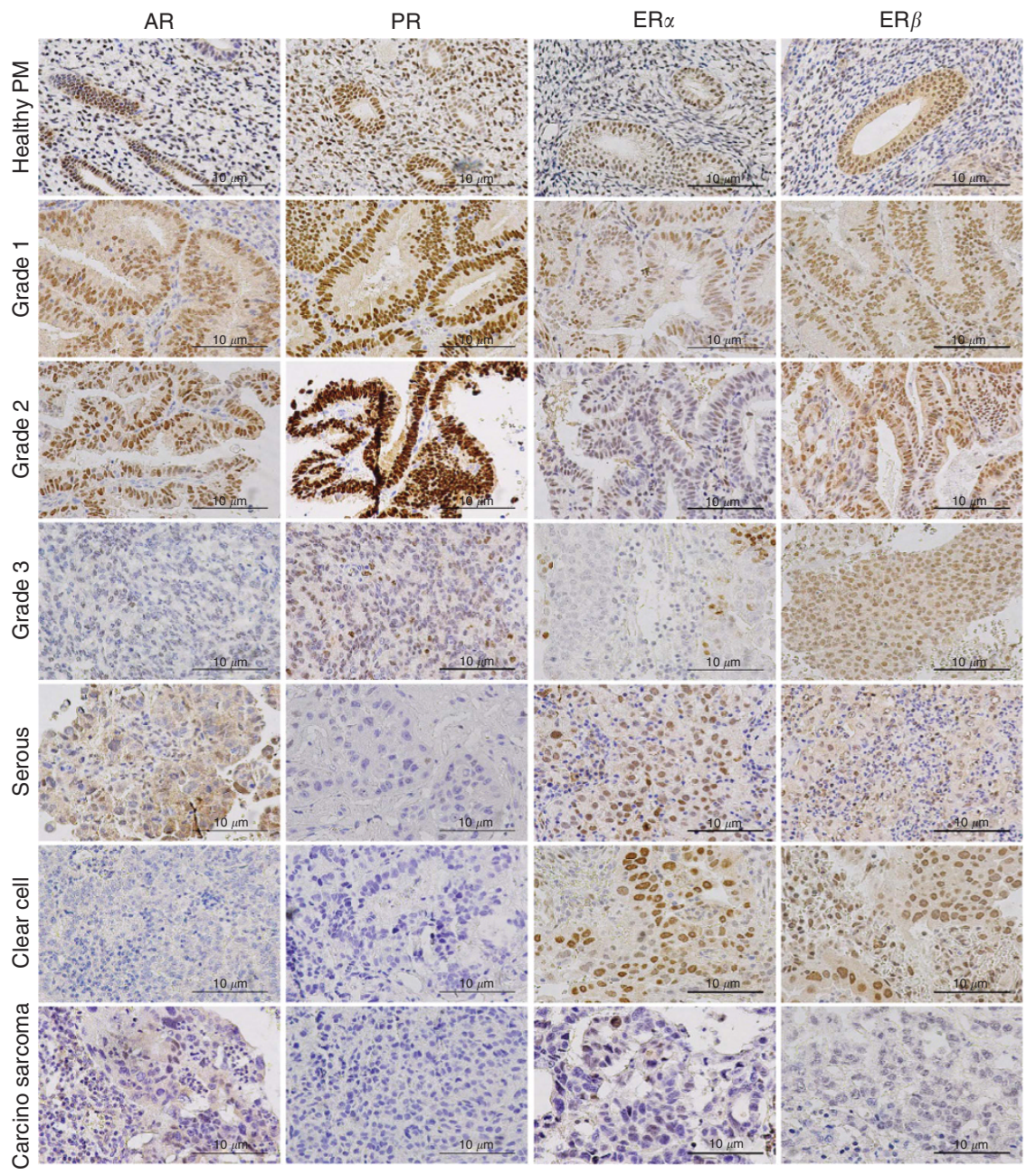

Figure 1. Representative photomicrographs of $A R, P R, E R \alpha$ and $E R \beta$ in human endometrium. Healthy PM endometrium, grade 1-3 endometrioid carcinoma, serous carcinoma, clear-cell carcinoma and carcinosarcoma were immunostained for AR, PR, ER $\alpha$ and ER $\beta$. Positive staining appears brown. Magnification $\times 400$.

receptor loss was limited to only 5 out of 15 (33.3\%) of the endometrioid HGEC. Expression of AR in non endometrioid HGEC was comparable to PR; 16 out of 33 (48.5\%) were ARnegative, and 13 of these were also negative for PR. Furthermore, only AR expression (not PR) reduced significantly with advanced FIGO stage (stage I $v s$ stage III, $P=0.006$, Figure $2 \mathrm{E}$ ).

Metastatic lesions aquire AR. Nuclear AR was observed in 10 out of $16(62.5 \%)$ (Figure $3 \mathrm{~A}$ ) metastatic lesions, and expression scores were significantly higher compared with the matched primary lesions $(P=0.03)$. By contrast, only 6 out of $15(40 \%)$ (Figure $3 \mathrm{~B})$ of metastatic lesions expressed PR. Although the median expression of Ki67 was generally lower in metastatic lesions (45\%) than in the matched primary tumour $(60 \%)$ (Supplementary Figure $1 \mathrm{~b} ; \mathrm{E}$ and F), the difference in the expression pattern of both PR and Ki67 between the two groups was not statistically significant (Figure 3C).

\footnotetext{
AR expression positively associates with favourable prognostic factors. Endometrial cancer epithelial AR correlated positively with PR $(r=0.63, P<0.0001)$, whilst there was a negative correlation with Ki67 $(r=-0.43, P=0.0004$, Supplementary Table 4). When expression of steroid receptors (as positive or negative) was correlated with each clinicopathological parameter, both $\mathrm{AR}$ and $\mathrm{PR}$ expression correlated positively with welldifferentiated tumours and those without cervical invasion, yet only AR expression showed positive correlation with early FIGO
}

stages $(P=0.048$, Supplementary Table 5$)$. Intriguingly, concurrent loss of $\mathrm{AR}$ and $\mathrm{PR}$ showed a significant positive correlation with higher tumour grades $(P<0.0001)$, late FIGO stages $(P=0.004)$, deep myometrial invasion $(P=0.003)$, extrauterine invasion $(P=0.048)$ and cervical invasion $(P<0.0001) . \mathrm{ER} \alpha$ did not show a significant correlation with clinicopathological parameters; however, a high $\mathrm{ER} \alpha / \mathrm{ER} \beta$ ratio was associated with invasion of the cervical stroma $(P=0.041)$ and showed a trend to be associated with advanced stage tumours $(P=0.057)$.

Loss of AR adversely influences patient outcome. Follow-up data were available for all EC patients. By January 2015 the median follow-up was 19 months, ranging between 6 and 40 months. During the follow-up period there were 5 recurrent tumours and 16 deaths (13 as a result of disease progression and 3 from other causes). ER $\alpha$ and $\mathrm{ER} \beta$ expression did not show a significant association with clinical outcome. A significant reduction in DFS was identified in the AR-negative group $(P=0.0001)$ and PRnegative group $(P=0.005)$. A subset of $E C$, which was negative for both AR and PR, showed a further decline in DFS $(P<0.0001)$. Moreover, patients with a high $\mathrm{ER} \alpha / \beta$ ratio had a worse prognosis (DFS, $P=0.023$ ) than those with a low $\mathrm{ER} \alpha / \beta$ ratio (Figure 4). Univariate analysis has shown that HGEC, advanced stages (III and IV), deep myometrial invasion, cervical invasion, loss of AR, loss of $\mathrm{PR}$, combined $\mathrm{AR} / \mathrm{PR}$ loss and high $\mathrm{ER} \alpha / \mathrm{ER} \beta$ ratio were significantly associated with progressive disease (Table 2). None of the other parameters was significantly associated with patient 
A

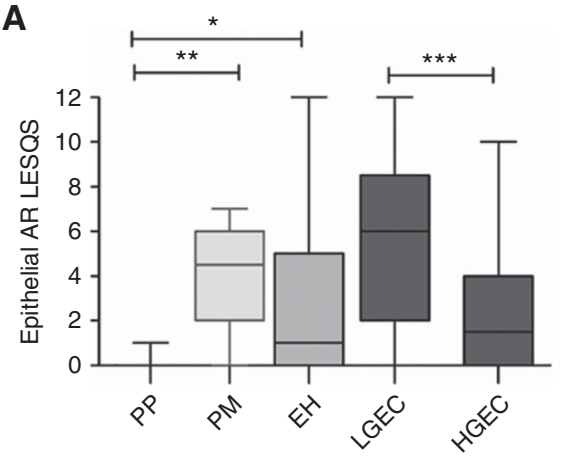

C

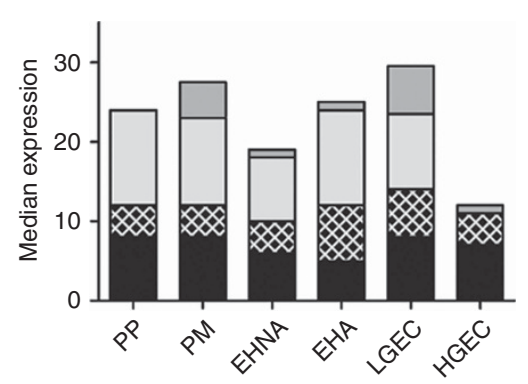

E

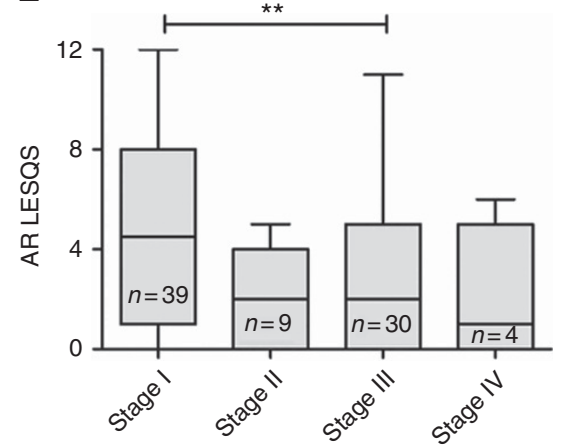

B

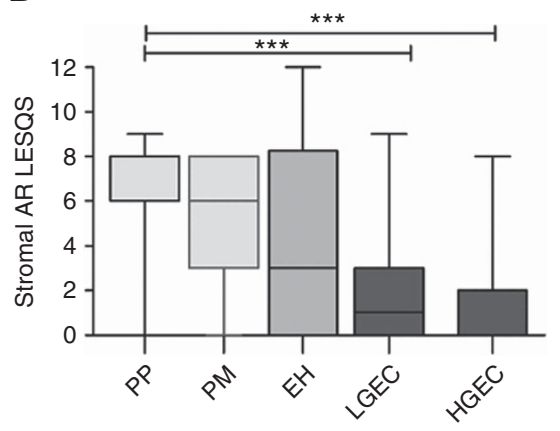

D

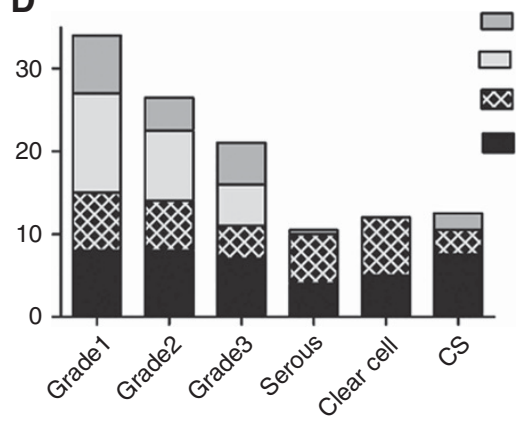

$\mathbf{F}$

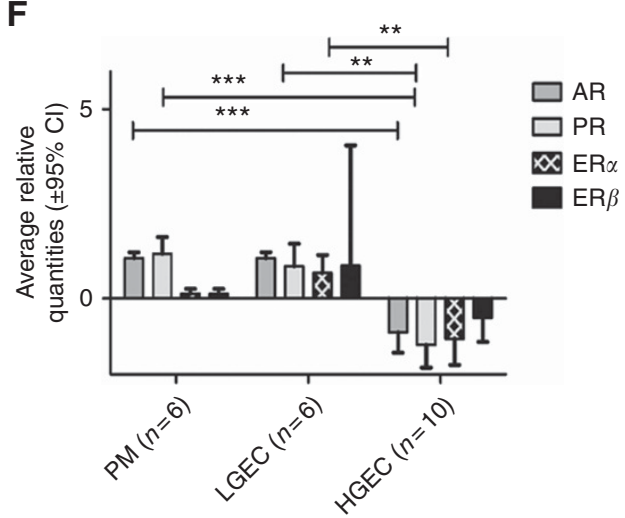

Figure 2. Protein and mRNA expression levels for Steroid receptors in endometrial cancer. (A) Expression of AR in the epithelium and (B) stroma of healthy PP, PM, endometrial hyperplasia (EH), LGEC and HGEC. (C, D) Stacked graphs represent the median expression of AR, PR, ER $\alpha$ and ER $\beta$ in (C) PP, PM, endometrial hyperplasia no atypia (EHNA), endometrial hyperplasia with atypia (EHA), LGEC and HGEC; (D) endometrial cancer subtypes, including carcinosarcoma (CS). (E) Expression of AR protein according to endometrial cancer stage. (F) Steroid receptor mRNA levels in human endometrial tissue, PM, LGEC and HGEC. ${ }^{\star} P<0.05,{ }^{*} P<0.001, * \star \star P<0.0001$.
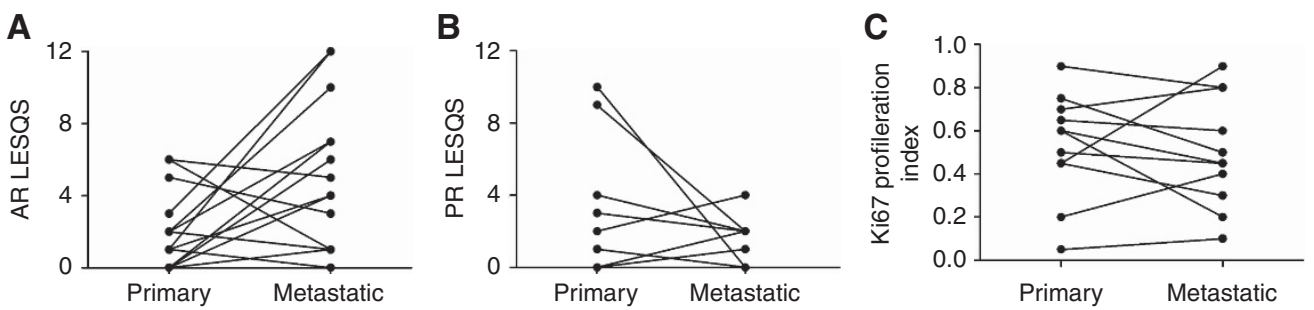

Figure 3. Immuno-expression scores of AR, PR and Ki67 in metastatic compared with matched primary tumours. (A) AR (B) PR and (C) Ki67.

outcome. Furthermore, Cox regression model confirmed that only AR $(P=0.007), \mathrm{ER} \alpha / \mathrm{ER} \beta(P=0.032)$, tumour grade $(P=0.047)$ and myometrial invasion $(P=0.008)$ were independent prognostic indicators (Table 2).

Steroid receptor mRNA levels reflect their protein expression. Consistent with the IHC results, a general decline in mRNA levels for all steroid receptors was observed in HGEC. This reduction was significant for AR $(P=0.0002)$ when compared with PM endometrium, and for $\operatorname{ER} \alpha(P=0.003)$ when compared with LGEC. PR transcript level in HGEC was significantly lower than both PM $(P=0.0002)$ and LGEC $(P=0.001)$. The change in $\operatorname{ER} \beta$ mRNA was not significant (Figure $2 \mathrm{~F})$. Furthermore, AR $(r=0.59$, $P=0.015)$ and PR $(r=0.74, P=0.001)$ mRNA levels also showed a 


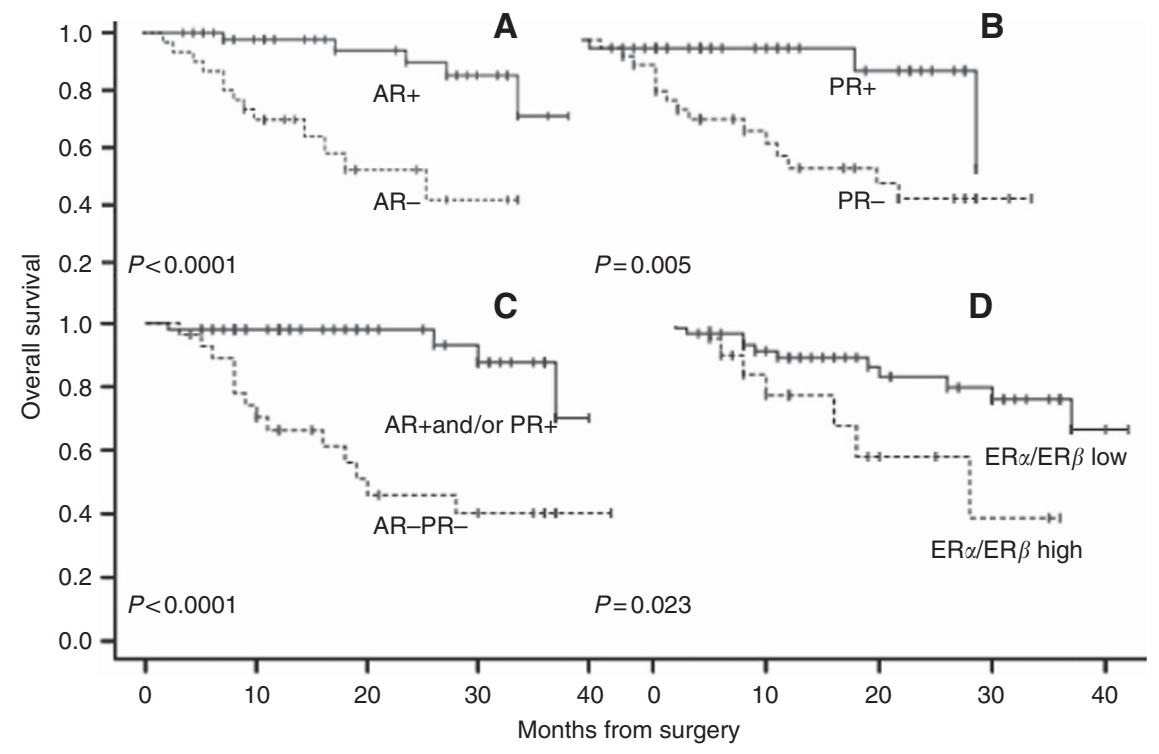

Figure 4. Kaplan-Meier survival curve for the probability of disease-free period relative to immunoexpression of (A) AR, (B) PR, (C) AR/PR negative and (D) ER $\alpha / E R \beta$ ratio.

Table 2. Univariate and multivariate analyses of disease-free survival

\begin{tabular}{|c|c|c|c|}
\hline \multirow[t]{2}{*}{ Variables } & Univariate & \multicolumn{2}{|c|}{ Multivariate } \\
\hline & $P$ & $P$ & $\mathrm{HR}(95 \% \mathrm{Cl})$ \\
\hline Age (years): $\leqslant 65$ vs $>65$ & 0.328 & Removed & - \\
\hline $\mathrm{BMI}^{\mathrm{a}}: \leqslant 30$ vs $>30$ & 0.531 & Removed & - \\
\hline Tumour stage: I-II vs III-IV & 0.029 & 0.579 & - \\
\hline Tumour grade: LG vs HG & 0.005 & 0.046 & $5.5(1.0-29.8)$ \\
\hline $\begin{array}{l}\text { Lymphovascular invasion: } \\
-v s+\end{array}$ & 0.097 & Removed & - \\
\hline $\begin{array}{l}\text { Myometrial invasion : } \leqslant 50 \% \text { vs } \\
>50 \%\end{array}$ & 0.002 & 0.008 & $8.8(1.8-44.2)$ \\
\hline Cervical stromal invasion: - vs + & 0.0001 & 0.073 & - \\
\hline Extra uterine invasion: $-v s+$ & 0.19 & Removed & - \\
\hline AR expression: $-v s+$ & 0.001 & 0.007 & $0.12(0.3-0.5)$ \\
\hline PR expression: - vs + & 0.012 & 0.771 & - \\
\hline AR - PR - expression: - vs + & 0.001 & 0.727 & - \\
\hline ER $\alpha$ expression: $-v s+$ & 0.547 & Removed & - \\
\hline ER $\beta$ expression: $-v s+$ & 0.895 & Removed & - \\
\hline $\mathrm{ER} \alpha / \beta$ ratio: $\leqslant 1$ vs $>1$ & 0.031 & 0.032 & $3.5(1.1-11.3)$ \\
\hline \multicolumn{4}{|c|}{ 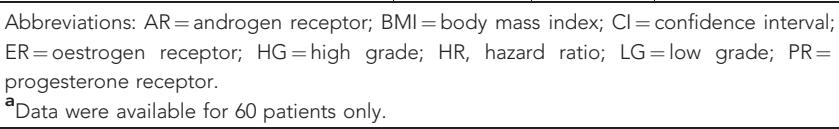 } \\
\hline
\end{tabular}

significant correlation with their protein expression scores (data not shown).

\section{DISCUSSION}

To our knowledge, this is the first comprehensive report comparing AR expression in healthy $\mathrm{PM}$ endometrium with healthy premenopausal PP endometrium and all EC subtypes, including non-endometrioid type II (serous and clear-cell carcinomas and carcinosarcoma) ECs and metastatic lesions. We have also described the contemporaneous expression scores for $\mathrm{ER} \alpha$, $\mathrm{ER} \beta$ and $\mathrm{PR}$ in serial sections of the same endometrial samples, allowing inferences to be made regarding their functional interplay in both healthy endometrium and in endometrial carcinogenesis.

Previous reports of steroid receptor protein expression in normal and pathological endometrium have used different semiquantification methods (Mertens et al, 2001; Critchley et al, 2002; Mylonas et al, 2007; Zannoni et al, 2013). Of the available quickscores, Allred and IRS have been commonly used to analyse steroid receptors in endometrium (Mylonas et al, 2007; Zannoni et al, 2013), but these two systems were optimised for ER and PR expression (not AR) specifically in breast tissue. We propose a LESQS, which is optimised for both normal and neoplastic endometrium. Importantly, LESQS had the best correlation with a standard $H$-score for AR and ER $\alpha$ compared with both Allred and IRS scores for either epithelial or stromal compartments. LESQS also showed high correlation with the $H$-score for PR and $\mathrm{ER} \beta$, similar to the Allred score correlation (Supplementary Table 6). In order to gain better insight into hormone actions, all cognate steroid receptors ( $\mathrm{AR}, \mathrm{ER} \alpha, \mathrm{ER} \beta$ and $\mathrm{PR}$ ) need to be assessed using the same scoring system; hence the optimised LESQS was chosen.

Postmenopausal endometrium is composed of inactive glands lying in a compact stroma that morphologically resembles the stratum basalis of premenopausal endometrium (McCluggage, 2011). Moreover, PM endometrium is characterised by the complete loss of the stratum functionalis; therefore, we compared the steroid expression in PM endometrium with that of PP stratum basalis. Interestingly, compared with PP stratum basalis, we found significantly higher levels of epithelial $A R$ and $E R \alpha$ in PM endometrium but similar ER $\beta$ and PR expression levels. Horie et al (1992) reported AR expression (albeit in a sample size of $n=4)$ in PM endometrial epithelium, which is consistent with our results, but they indicated the AR expression levels to be similar to PP stratum basalis. Their use of a small sample size without quantifying the immunostaining may explain the differences in conclusion between the two studies. In contrast, a previous report comparing $\mathrm{PM}$ endometrium with $\mathrm{PP}$ stratum functionalis suggested a decrease of $\mathrm{ER} \alpha, \mathrm{ER} \beta$ and $\mathrm{PR}$ expression in PM epithelial cells (Mylonas et al, 2007). The PM hormonal milieu is characterised by the absence of progesterone and oestradiol, the presence of low levels of circulating oestrone (Sivridis and Giatromanolaki, 2004) and persisting levels of androgens from the adrenals, which may support the maintenance of endometrial PR and ER expression. Although there are reports suggesting focal 
and weak epithelial AR expression appearing in late secretory phase endometrium, presumed to be associated with progesterone withdrawal (Horie et al, 1992; Mertens et al, 2001), the most prominent feature of premenopausal secretory phase endometrium is the high levels of stromal AR expression. This is in contrast with $\mathrm{PM}$ endometrium, where dominant $\mathrm{AR}$ staining is in the epithelium. Furthermore, anti-progesterone (mifepristone) administration was associated with upregulation of both stromal and epithelial AR expression in premenopausal primate endometrium (Slayden and Brenner, 2004), yet we observed the stromal AR to be low in PM compared with PP endometrium. As by definition, PM endometrium has not been exposed to progesterone for at least 12 months, the appearance of epithelial AR in PM endometrium cannot be equated merely to progesterone withdrawal. To complicate matters further, mifepristone is not only a progesterone antagonist but also has anti-androgenic and glucocorticoid properties (Hapangama, 2003). Therefore, the appearance of AR in PM epithelium may be induced by the action of either oestrone via $\mathrm{ER} \alpha$ or androgens via $\mathrm{AR}$ (Fujimoto et al, 1994; Lovely et al, 2000). Interestingly, the upregulation of PM epithelial AR was not associated with high cell proliferation (assessed by Ki67), which would be expected to be present with classical ER $\alpha$-mediated epithelial action. Short-term treatment with testosterone was associated with low PI in normal PM women (Zang et al, 2007). Consistent with in vitro studies (Tuckerman et al, 2000; Gibson et al, 2014), this indicates a direct androgen-driven induction of $\mathrm{AR}$, resulting in an inhibition of PM epithelial proliferation. Taking in account that stromal AR has been described to have an antiapoptotic role (Marshall et al, 2011), AR seems to have a cellspecific function in the endometrium.

Endometrial hyperplasia with atypia is a premalignant condition (Lacey et al, 2008) with molecular aberrations (Steinbakk et al, 2011) and morphological changes that are typical for unopposed oestrogenic activity. Consistent with previous reports, the epithelial expression of AR in EHA was higher than that in PP endometrium (Ito et al, 2002), whereas the PI of EHA did not differ from that of PP endometrium. Intriguingly, compared with PM endometrium, AR scores were relatively lower in EHA, with a significantly high Ki67 confirming oestrogen-driven cell proliferation.

The available data on steroid receptor expression in EC subtypes are largely confined to endometrioid EC focusing on $\mathrm{ER} \alpha, \mathrm{ER} \beta$ and PR (Deligdisch et al, 2000; Kounelis et al, 2000; Collins et al, 2009). Traditionally, type II ECs are considered to be hormonally independent; there are only limited reports of ER and PR expression (Alkushi et al, 2010; Mhawech-Fauceglia et al, 2013), with no previous data on $\mathrm{AR}$ and $\operatorname{ER} \beta$ expression in serous and clear-cell carcinomas and carcinosarcomas (Hapangama et al, 2015). However, recent reports indicate that both type I and II ECs have similar risk factors (Setiawan et al, 2013). Studies describing AR expression in endometrioid EC are scarce and inconsistent. Horie et al (1992) reported positive AR expression in four grade 2 EC samples. In our study, most LGECs expressed AR (protein and transcript), and the LGEC immunoscores did not significantly differ from those of PM controls. Grade 3 endometrioid EC, however, expressed lower levels of AR consistent with the previous report (Ito et al, 2002). Conflicting reports have suggested that AR is absent in $72 \%$ ECs (Sasaki et al, 2000), although, in that particular study, the specific histological type was not described for all samples. In agreement with our results, others have reported downregulation of PR in non-endometrioid HGEC (Alkushi et al, 2010). Interestingly, in comparison with LGECs, HGEC showed a significant decline of both $\mathrm{PR}$ and AR protein expression, whereas the decrease in $\mathrm{ER} \alpha$ was not significant. This was particularly evident in clear-cell carcinoma, although conflicting reports have shown a reduction of $\mathrm{ER}$ (without distinguishing $\mathrm{ER} \alpha$ or $\mathrm{ER} \beta$ subtypes) in clear-cell EC (Hoang et al, 2013; Mhawech-Fauceglia et al, 2013). Differences in sample size and methodology (antibodies and immunoanalysis) are likely to be the explanation for this discrepancy. In agreement with our data, the recent TCGA data also suggest AR expression to be a feature of LGECs with better prognosis (Kandoth et al, 2013). Furthermore, it was interesting that although ESR1 $(\mathrm{ER} \alpha)$ and PGR (PR) gene mutation was seen in endometrial cancers with favourable outcome, AR mutations were not identified in the large TCGA data set, suggesting the therapeutic potential of AR receptor modulators in EC.

From these results, it is tempting to speculate that even in presumed 'hormonally independent' non-endometrioid HGEC, $\mathrm{ER} \alpha$ and $\operatorname{ER} \beta$ receptors were expressed relatively abundantly (with concomitant loss of $\mathrm{AR}$ and $\mathrm{PR}$ ), resulting in possible unopposed oestrogenic activity.

Our data examined AR expression in metastatic lesions for the first time, and demonstrated significantly higher AR expression than in the matched primary tumours. Although molecular and biological characteristics of macro-metastases are not well defined, endometrial metastatic epithelial cells have been reported to express oestrogen receptors, ER $\beta$ in particular (Fujimoto et al, 2002). The metastatic lesions examined in the present study showed some similarities with the primary tumours such as the PR expression and PI. Sixty per cent of these lesions showed loss of PR, consistent with previous reports (Tangen et al, 2014) but interestingly, in these lesions, AR expression was significantly upregulated. Low PR expression may explain the poor clinical response observed in a majority $(66 \%)$ of patients with recurrent or metastatic tumours to progesterone treatment (Fiorica et al, 2004). The re-emergence of AR expression in these lesions, however, produces a possible novel adjuvant therapeutic opportunity.

Unlike breast cancer, the literature on the prognostic value of $\mathrm{ER} \alpha, \mathrm{ER} \beta, \mathrm{ER} \alpha / \mathrm{ER} \beta$ ratio and $\mathrm{PR}$ in $\mathrm{EC}$ is inconsistent, probably owing to methodological variations (Takama et al, 2001; Fujimoto et al, 2002; Shabani et al, 2007; Jongen et al, 2009; Zannoni et al, 2013). Our results have shown that $A R$ and $P R$ expression is associated with longer DFS in patients with EC, and this is consistent with other recent reports (Tanaka et al, 2014; Tangen et al, 2014), and concurrent loss of both $\mathrm{AR}$ and PR was associated with a higher risk of relapse. Moreover, loss of AR and PR correlated positively with unfavourable clinicopathological parameters that predict poor clinical outcome such as high-grade, deep myometrial invasion and cervical stromal involvement, and advanced FIGO stages. AR may also bind progesterone, which is the main hormonal therapy in EC, and subsequently may mediate inhibition of cell proliferation (Hackenberg and Schulz, 1996). Further, emerging evidence indicates that androgens, unlike progestin, may induce PR expression (Park et al, 2014). Therefore, besides the prognostic significance, expression data on AR and PR may be a useful clinically as a potential therapeutic target to tailor adjuvant hormonal therapy for intermediate and higher-risk EC. We have also shown a high $\mathrm{ER} \alpha / \mathrm{ER} \beta$ ratio to be significantly associated with shorter DFS, and this is likely to be due to a relative reduction in expression of the guardian protein, $\operatorname{ER} \beta$, that counteracts mitogenic $\mathrm{ER} \alpha$ activity (Hapangama et al, 2015). These data conflict with some previous reports that only examined endometrioid EC, using either mRNA levels or different quantification methods of IHC staining (Takama et al, 2001; Zannoni et al, 2013).

We acknowledge that this is an observational analytic study, which requires further functional and genetic investigations in the future to confirm the clinical relevance of these findings. Further work will also evaluate the potential therapeutic effects of selective AR modulators in the management of advanced EC. Further, we believe that the characterisation of metastatic lesions for steroid receptor expression in a larger sample series ideally before and after hormonal therapy may unveil the reasons behind the limited responsiveness of EC to hormonal therapy. Our LESQS scoring 
system will provide a standard and clinically applicable tool for researchers to undertake these important future studies.

\section{CONCLUSIONS}

Healthy PM endometrial epithelial cells acquire AR compared with healthy premenopausal proliferative endometrium, whilst $\mathrm{ER} \alpha$, $\mathrm{ER} \beta$ and $\mathrm{PR}$ expression is maintained. Nuclear epithelial AR expression appears to be associated with an anti-proliferative phenotype suggesting a cell-type-specific function of androgen. In $\mathrm{EC}$, loss of $\mathrm{AR}$ and $\mathrm{PR}$ with persistent $\mathrm{ER} \alpha$ and $\mathrm{ER} \beta$ expression may promote the unrestrained growth and propagation observed in HGEC. Therefore, ER subtypes may potentially represent a therapeutic target in HGEC, whilst AR may be a clinically relevant prognostic indicator.

\section{ACKNOWLEDGEMENTS}

We are grateful for Veda Avula, Eve Bunni and Druvi Edirisinghe for assistance in IHC, and Dr Steven Lane for statistical advice. We acknowledge the support from Wellbeing of Women project grant RG1487 (DKH) and Higher Committee for Education Development in Iraq (AMK).

\section{CONFLICT OF INTEREST}

The authors declare no conflict of interest.

\section{REFERENCES}

Al Kushi A, Lim P, Aquino-Parsons C, Gilks CB (2002) Markers of proliferative activity are predictors of patient outcome for low-grade endometrioid adenocarcinoma but not papillary serous carcinoma of endometrium. Mod Pathol 15: 365-371.

Alkushi A, Köbel M, Kalloger SE, Gilks CB (2010) High-grade endometrial carcinoma: serous and grade 3 endometrioid carcinomas have different immunophenotypes and outcomes. Int J Gynecol Pathol 29: 343-350.

Bokhman JV (1983) Two pathogenetic types of endometrial carcinoma. Gynecol Oncol 15: 10-17.

Breast Cancer Consensus C, Clinical Oncological Society Of A, Australian New Zealand Breast Cancer Trials G (1994) Consensus Report from Australia's First National Breast Cancer Consensus Conference, June 15-17 1994. Australian-New Zealand Breast Cancer Trials Group: Newcastle, NSW, Australia.

Cancer Research UK (2013) Cancer Stats Report: Uterine (Womb) Cancer [online]. Available at http://www.cancerresearchuk.org/healthprofessional/cancer-statistics/statistics-by-cancer-type/uterinecancer\#heading-Zero (accessed on June 2015).

Collins F, Macpherson S, Brown P, Bombail V, Williams A, Anderson R, Jabbour H, Saunders P (2009) Expression of oestrogen receptors, eralpha, erbeta, and erbeta variants, in endometrial cancers and evidence that prostaglandin $\mathrm{f}$ may play a role in regulating expression of eralpha. BMC Cancer 9: 330-330.

Critchley HOD, Henderson TA, Kelly RW, Scobie GS, Evans LR, Groome NP, Saunders PTK, Critchley HOD, Henderson TA, Kelly RW, Scobie GS, Evans LR, Groome NP, Saunders PTK (2002) Wild-type estrogen receptor (erbeta1) and the splice variant (erbetacx/beta2) are both expressed within the human endometrium throughout the normal menstrual cycle. J Clin Endocrinol Metab 87: 5265-5273.

Dallenbach-Hellweg G, Schmidt D, Dallenbach F (2010) Normal endometrium. In Atlas of Endometrial histopathology, Chapter 3, pp 7-44. Springer: Berlin Heidelberg.

Deligdisch L, Kase NG, Bleiweiss IJ (2000) Endometrial cancer in elderly women: a histologic and steroid receptor study. Gerontology 46: 17-21.

Fiorica JV, Brunetto VL, Hanjani P, Lentz SS, Mannel R, Andersen W (2004) Phase II trial of alternating courses of megestrol acetate and tamoxifen in advanced endometrial carcinoma: a gynecologic oncology group study. Gynecol Oncol 92: 10-14.

Fujimoto J, Nishigaki M, Hori M, Ichigo S, Itoh T, Tamaya T (1994) The effect of estrogen and androgen on androgen receptors and mRNA levels in uterine leiomyoma, myometrium and endometrium of human subjects. J Steroid Biochem Mol Biol 50: 137-143.

Fujimoto J, Sakaguchi H, Aoki I, Toyoki H, Tamaya T (2002) Clinical implications of the expression of estrogen receptor- $\alpha$ and $-\beta$ in primary and metastatic lesions of uterine endometrial cancers. Oncology 62: 269-277.

Gibson DA, Simitsidellis I, Collins F, Saunders PT (2014) Evidence of androgen action in endometrial and ovarian cancers. Endocr Relat Cancer 21: T203-T218.

Hackenberg R, Schulz KD (1996) Androgen receptor mediated growth control of breast cancer and endometrial cancer modulated by antiandrogen- and androgen-like steroids. J Steroid Biochem Mol Biol 56: 113-117.

Hapangama D (2003) Mifepristone: the multi-faceted anti-hormone. J Drug Eval 1: 149-175.

Hapangama DK, Kamal AM, Bulmer JN (2015) Estrogen receptor $\beta$ : the guardian of the endometrium. Hum Reprod Update 21(2): 174-193.

Hapangama DK, Raju RS, Valentijn AJ, Barraclough D, Hart A, Turner MA, Platt-Higgins A, Barraclough R, Rudland PS (2012) Aberrant expression of metastasis-inducing proteins in ectopic and matched eutopic endometrium of women with endometriosis: implications for the pathogenesis of endometriosis. Hum Reprod 27: 394-407.

Hoang LN, Han G, Mcconechy M, Lau S, Chow C, Gilks CB, Huntsman DG, Kobel M, Lee CH (2013) Immunohistochemical characterization of prototypical endometrial clear cell carcinoma-diagnostic utility of hnf1beta and oestrogen receptor. Histopathology 64: 585-596.

Horie K, Takakura K, Imai K, Liao S, Mori T (1992) Immunohistochemical localization of androgen receptor in the human endometrium, decidua, placenta and pathological conditions of the endometrium. Hum Reprod 7: 1461-1466.

Ito K, Suzuki T, Akahira J-I, Moriya T, Kaneko C, Utsunomiya H, Yaegashi N, Okamura K, Sasano H (2002) Expression of androgen receptor and 5alpha-reductases in the human normal endometrium and its disorders. Int J Cancer 99: 652-657.

Jongen V, Briet J, De Jong R, Ten Hoor K, Boezen M, Van Der Zee A, Nijman H, Hollema H (2009) Expression of estrogen receptor-alpha and -beta and progesterone receptor-a and - $\mathrm{b}$ in a large cohort of patients with endometrioid endometrial cancer. Gynecol Oncol 112 537-542.

Kandoth C, Schultz N, Cherniack AD, Akbani R, Liu Y, Shen H, Robertson AG, Pashtan I, Shen R, Benz CC, Yau C, Laird PW, Ding L, Zhang W, Mills GB, Kucherlapati R, Mardis ER, Levine DA (2013) Integrated genomic characterization of endometrial carcinoma. Nature 497: 67-73.

Kounelis S, Kapranos N, Kouri E, Coppola D, Papadaki H, Jones MW (2000) Immunohistochemical profile of endometrial adenocarcinoma: a study of 61 cases and review of the literature. Mod Pathol 13: 379-388.

Lacey JV, Richesson DA, Sherman ME, Ioffe OB, Ronnett BM, Rush BB, Glass AG, Chatterjee N, Langholz B (2008) Endometrial carcinoma risk among women diagnosed with endometrial hyperplasia: the 34-year experience in a large health plan. Br J Cancer 98: 45-53.

Lindemann K, Eskild A, Vatten LJ, Bray F (2010) Endometrial cancer incidence trends in norway during 1953-2007 and predictions for 2008-2027. Int J Cancer 127: 2661-2668.

Lovely LP, Appa Rao KBC, Gui Y, Lessey BA (2000) Characterization of androgen receptors in a well-differentiated endometrial adenocarcinoma cell line (ishikawa). J Steroid Biochem Mol Biol 74: 235-241.

Marshall E, Lowrey J, Macpherson S, Maybin JA, Collins F, Critchley HOD, Saunders PTK (2011) In silico analysis identifies a novel role for androgens in the regulation of human endometrial apoptosis. $J$ Clin Endocrinol Metab 96: E1746-E1755.

McCluggage WG (2011) Benign diseases of the endometrium. In Pathology of Female Genetal Tract, Kurman R, Ellenson L, Ronnett B (eds), pp 305-358. Springer: Boston, USA.

Mertens HJ, Heineman MJ, Theunissen PH, De Jong FH, Evers JL (2001) Androgen, estrogen and progesterone receptor expression in the human uterus during the menstrual cycle. Eur J Obstet Gynecol Reprod Biol 98: $58-65$.

Mhawech-Fauceglia P, Yan L, Liu S, Pejovic T (2013) ER + /PR + /TFF3 + /IMP3- immunoprofile distinguishes endometrioid from serous and clear 
cell carcinomas of the endometrium: a study of 401 cases. Histopathology 62: 976-985.

Murali R, Soslow RA, Weigelt B (2014) Classification of endometrial carcinoma: more than two types. Lancet Oncol 15: e268-e278.

Mylonas I, Jeschke U, Shabani N, Kuhn C, Kunze S, Dian D, Friedl C, Kupka MS, Friese K (2007) Steroid receptors ERalpha, ERbeta, PR-A and PR-B are differentially expressed in normal and atrophic human endometrium. Histol Histopathol 22: 169-176.

Noyes RW, Hertig AT, Rock J (1950) Dating the endometrial biopsy. Fertil Steril 1: 3-25.

Park C, Babayev S, Carr BR, Keller PW, Word RA, Bukulmez O (2014) Androgen regulation of progesterone receptor (PR) expression in endometrium: implications for endometriosis [abstract]. Fertil Steril 102: e79-e80.

Pertschuk LP, Masood S, Simone J, Feldman JG, Fruchter RG, Axiotis CA, Greene GL (1996) Estrogen receptor immunocytochemistry in endometrial carcinoma: a prognostic marker for survival. Gynecol Oncol 63: $28-33$.

Sadek KH, Cagampang FR, Bruce KD, Shreeve N, Macklon N, Cheong Y (2011) Variation in stability of housekeeping genes in endometrium of healthy and polycystic ovarian syndrome women. Hum Reprod 27: 251-256.

Sasaki M, Dharia A, Dahiya R, Oh BR, Fujimoto S (2000) Inactivation of the human androgen receptor gene is associated with cpg hypermethylation in uterine endometrial cancer. Mol Carcinog 29: 59-66.

Setiawan VW, Yang HP, Pike MC, Mccann SE, Yu H, Xiang YB, Wolk A, Wentzensen N, Weiss NS, Webb PM, Van Den Brandt PA, Van De Vijver K, Thompson PJ. Australian National Endometrial Cancer Study G, Strom BL, Spurdle AB, Soslow RA, Shu XO, Schairer C, Sacerdote C, Rohan TE, Robien K, Risch HA, Ricceri F, Rebbeck TR, Rastogi R, Prescott J, Polidoro S, Park Y, Olson SH, Moysich KB, Miller AB, Mccullough ML, Matsuno RK, Magliocco AM, Lurie G, Lu L, Lissowska J, Liang X, Lacey Jr JV, Kolonel LN, Henderson BE, Hankinson SE, Hakansson N, Goodman MT, Gaudet MM, Garcia-Closas M, Friedenreich CM, Freudenheim JL, Doherty J, De Vivo I, Courneya KS, Cook LS, Chen C, Cerhan JR, Cai H, Brinton LA, Bernstein L, Anderson KE, Anton-Culver H, Schouten LJ, Horn-Ross PL (2013) Type I and II endometrial cancers: have they different risk factors? J Clin Oncol 31: 2607-2618.

Shabani N, Kuhn C, Kunze S, Schulze S, Mayr D, Dian D, Gingelmaier A, Schindlbeck C, Willgeroth F, Sommer H, Jeschke U, Friese K, Mylonas I (2007) Prognostic significance of oestrogen receptor alpha (ER alpha) and beta (ER beta), progesterone receptor A (PR-A) and B (PR-B) in endometrial carcinomas. Eur J Cancer Clin Oncol 43: 2434-2444.

Singh M, Zaino RJ, Filiaci VJ, Leslie KK (2007) Relationship of estrogen and progesterone receptors to clinical outcome in metastatic endometrial carcinoma: a gynecologic oncology group study. Gynecol Oncol 106: 325-333.

Sivridis E, Giatromanolaki A (2004) Proliferative activity in postmenopausal endometrium: the lurking potential for giving rise to an endometrial adenocarcinoma. J Clin Pathol 57: 840-844.

Slayden D, Brenner RM (2004) Hormonal regulation and localization of estrogen, progestin and androgen receptors in the endometrium of nonhuman primates: effects of progesterone receptor antagonists. Arch Histol Cytol 67: 393-409.

Steinbakk A, Gudlaugsson E, Aasprong OG, Skaland I, Janssen EAM, Baak JP, Malpica A, Feng W (2011) Molecular biomarkers in endometrial hyperplasias predict cancer progression. Am J Obstet Gynecol 204: 357.e1-357.e12.

Tagnon HJ (1977) Antiestrogens in treatment of breast cancer. Cancer 39: 2959-2964.

Takama F, Kanuma T, Wang D, Kagami I, Mizunuma H (2001) Oestrogen receptor $\beta$ expression and depth of myometrial invasion in human endometrial cancer. Br J Cancer 84: 545-549.

Talhouk A, Mcconechy MK, Leung S, Li-Chang HH, Kwon JS, Melnyk N, Yang W, Senz J, Boyd N, Karnezis AN, Huntsman DG, Gilks CB, Mcalpine JN (2015) A clinically applicable molecular-based classification for endometrial cancers. Br J Cancer 113: 299-310.

Tanaka S, Miki Y, Hashimoto C, Takagi K, Doe Z, Li B, Yaegashi N, Suzuki T, Ito $\mathrm{K}$ (2014) The role of $5 \alpha$-reductase type 1 associated with intratumoral dihydrotestosterone concentrations in human endometrial carcinoma. Mol Cell Endocrinol.

Tangen IL, Werner HMJ, Berg A, Halle MK, Kusonmano K, Trovik J, Hoivik EA, Mills GB, Krakstad C, Salvesen HB (2014) Original research: loss of progesterone receptor links to high proliferation and increases from primary to metastatic endometrial cancer lesions. Eur J Cancer 50: 3003-3010.

Thike A, Chng M, Fook-Chong S, Tan P (2001) Immunohistochemical expression of hormone receptors in invasive breast carcinoma: correlation of results of h-score with pathological parameters. Pathology 33: 21-25.

Tuckerman EM, Okon MA, Li TC, Laird SM (2000) Do androgens have a direct effect on endometrial function? An in vitro study. Fertil Steril 74: 771-779.

Voss MA, Ganesan R, Ludeman L, Mccarthy K, Gornall R, Schaller G, Wei W, Sundar S (2012) Should grade 3 endometrioid endometrial carcinoma be considered a type 2 cancer-a clinical and pathological evaluation. Gynecol Oncol 124: 15-20.

Zaino RJ, Kurman RJ, Diana KL, Morrow CP (1995) The utility of the revised international federation of gynecology and obstetrics histologic grading of endometrial adenocarcinoma using a defined nuclear grading system: a gynecologic oncology group study. Cancer 75: 81-86.

Zang H, Sahlin L, Masironi B, Eriksson E, Hirschberg A (2007) Effects of testosterone treatment on endometrial proliferation in postmenopausal women. J Clin Endocrinol Metab 92: 2169-2175.

Zannoni GF, Monterossi G, De Stefano I, Gargini A, Salerno MG, Farulla I, Travaglia D, Vellone VG, Scambia G, Gallo D (2013) The expression ratios of estrogen receptor alpha (ERalpha) to estrogen receptor betal (ERbeta1) and ERalpha to ERbeta2 identify poor clinical outcome in endometrioid endometrial cancer. Hum Pathol 44: 1047-1054.

Zhang Y, Zhao D, Gong C, Zhang F, He J, Zhang W, Zhao Y, Sun J (2015) Prognostic role of hormone receptors in endometrial cancer: a systematic review and meta-analysis. World J Surg Oncol 13: 208.

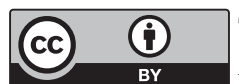

This work is licensed under the Creative Commons Attribution 4.0 International License. To view a copy of this license, visit http://creativecommons.org/licenses/by/4.0/

Supplementary Information accompanies this paper on British Journal of Cancer website (http://www.nature.com/bjc) 